\title{
REKAYASA PERANGKAT LUNAK CROWFUNDING BASIRU MENGGUNAKAN PEMROGRAMAN PHP DAN FREAMWORK CODEIGNITER
}

\author{
Sulastari $^{1}$, Farida Idifitriani $^{2}$, Nora Dery Sofya ${ }^{3}$ \\ ${ }^{1}$ Mahasiswa Informatika, Universitas Teknologi Sumbawa \\ ${ }^{2}$ Dosen Informatika, Universitas Teknologi Sumbawa \\ ${ }^{3}$ Dosen Informatika, Universitas Teknologi Sumbawa \\ Email : sulasrp115@gmail.com ${ }^{1}$
}

\begin{abstract}
Abstrak : Tradisi basiru, merupakan cerminan hidup kolektif masyarakat Sumbawa, yang memegang prinsip saling tolongmenolong. Kegiatan yang mencerminkan prinsip gotong royong salah satunya adalah pengumpulan atau urun dana dari masyarakat untuk mendukung suatu kegiatan tertentu yang sifatnya donasi/amal. Crowdfunding merupakan sebuah metode dalam penggalangan dana. Crowdfunding yang dimaksud dalam penelitian ini merupakan sebuah bentuk pendanaan yang menggunakan aplikasi berbasis website sebagai perantara penggalangan dana. Sedangkan model crowdfunding yang akan digunakan adalah Donation Based Crowdfunding. Adapun metode pengumpulan data yang digunakan dalam penelitian ini yaitu menggunakan metode kualitatif dan dalam perancangannya menggunakan Unifed Modelling Language (UML) dan metode pengembangan yang digunakan adalah metode Spiral sebagai metode pengembangan perangkat lunak. Pengembangan Sistem Crowfunding Basiru Menggunakan PHP dan Freamwork Codeigniter ini dibangun menggunakan bahasa pemrograman PHP, Visual Studio Code dan basis data MySQL sebagai Database Management System (DBMS) sehingga lebih efisien. Adapun metode pengujian perangkat lunak yang digunakan yaitu metode pengujian perangkat lunak black box yaitu menguji perangkat dari segi fungsionalitas.
\end{abstract}

Kata Kunci : Basiru, Crowfunding, Rekayasa Perangkat Lunak, Metode Kualtatif, Metode Spiral, Framework Codeigniter, PHP, Black Box.

Abstract : The basiru tradition is a reflection of the collective life of the Sumbawa people, which holds the principle of mutual help. One of the activities that reflect the principle of gotong royong is the collection or crowdfunding of funds from the community to support certain activities that are donations/charities. Crowdfunding is a method of raising funds. Crowdfunding referred to in this study is a form of funding that uses a website-based application as a fundraising intermediary. While the crowdfunding model that will be used is Donation Based Crowdfunding. The data collection method used in this research is using qualitative methods and in its design using the Unified Modeling Language (UML) and the development method used is the Spiral method as a software development method. Basiru Crowfunding System Development Using PHP and Codeigniter Freamwork was built using the PHP programming language, Visual Studio Code and MySQL database as a Database Management System (DBMS) so that it is more efficient. The software testing method used is the black box software testing method, namely testing the device in terms of functionality.

Keywords : Basiru, Crowfunding, Software Engineering, Qualitative Method, Spiral Method, Codeigniter Framework, PHP, Black Box.

\section{PENDAHULUAN}

\section{Latar Belakang}

Tradisi besiru, merupakan cerminan hidup kolektif masyarakat Sumbawa, yang memegang prinsip saling tolong-menolong. Kegiatan yang mencerminkan prinsip gotong royong salah satunya adalah pengumpulan atau urun dana dari masyarakat untuk mendukung suatu kegiatan tertentu yang sifatnya donasi/amal. Pengumpulan atau urun dana dari masyarakat ini mencakup masyarakat kecil sampai dengan masyarakat dalam lingkup nasional yang saat ini dilakukan dengan menggunakan media internet.

Crowdfunding merupakan sebuah metode dalam penggalangan dana. Crowdfunding yang dimaksud dalam penelitian ini merupakan sebuah bentuk pendanaan yang menggunakan aplikasi berbasis website sebagai perantara penggalangan dana.

Adapun metode penelitian yang digunakan penulis dalam penelitian ini yaitu metode kualitatif. Penelitian kualitatif merupakan pengumpulan data pada suatu latar ilmiah dengan tujuan menafsirkan fenomena yang terjadi dimana peneliti adalah sebagai instrumen kunci, dan hasil penelitian kualitatif lebih menekankan makna dari pada generalisasi (Anggito \& Setiawan, 2018).

\section{Tujuan Penelitian}

Penulis bertujuan untuk membuat sistem pengalangan dana berbasis web untuk memberikan bantuan kepada orang-orang yang mebutuhkan, baik itu yang terkena bencana, musibah, dan lain sebagainya. Berdasarkan uraian diatas maka akan dibuat tugas akhir dengan judul " Rekayasa Perangkat 
Lunak Crowfunding Basiru Menggunakan Pemrograman Php Dan Freamwork Codeigniter.“.

\section{Batasan Masalah}

Adapun Batasan masalah dalam penelitian ini yaitu :

1. Membuat sistem penggalangan dana menggunaka metode Crowdfunding.

2. Sistem ini berbasis website menggunakan Framework Codeigniter yang dimana tempat membuat CSS (Cascanding Style Sheets).

3. Sistem ini mengelola data pendanaan dan data para donatur.

4. Bahasa pemrograman yang digunakan adalah PHP.

5. Text Editor program yang digunakan adalah Visual Studio Code.

6. Database yang digunakan adalah $M y S Q L$.

7. Web server yang digunakan adalah Xampp.

\section{TINJAUAN PUSTAKA}

Adapun tinjauan pustaka yang dapat mendukung dalam penelitian ini diantaranya : ${ }^{[1]}$ Menurut Saifullah (2017) dalam skripsinya yang berjudul Sistem Penggalangan Dana Menggunakan Metode Crowdfunding Pada Lembaga Amil Zakat Infak Dan Sedekah (Lazis) Wahdah Berbasis Website, telah menganalisa pengelolaan donasi dari para donatur membutuhkan proses yang lama serta pencairan dana yang tidak transparan. Tidak efisiennya proses tersebut sehingga pengumpulan data-data donasi dari para donatur dan pencairan dana terkadang menjadi permasalah pada lembaga amil zakat infak dan sedekah lazis wahdah serta minat masyarakat untuk bersedekah yang kurang.

Tujuan dari penelitian ini untuk membuat suatu sistem penggalangan dana menggunakan metode crowdfunding pada lembaga amil zakat infak dan sedekah (lazis) Wahdah berbasis website sehingga donatur dapat mengetahui sedekahnya didonasikan kemana dan dalam bentuk program apa pada lembaga tersebut.

Adapun metode peneltian yang digunakan adalah metode kualitatif dan metode perancangan yang digunakan adalah metode waterfall. Sistem ini berbasis Website. Pemodelannya menggunakan flowchart dan diuji dengan metode pengujian blackbox. Kesimpulannya adalah dapat memudahkan dalam melakukan proses donasi, pengumpulan data donatur, dan laporan yang transparan serta penyimpanan data dengan baik. Penelitian ini memiliki kesamaan dengan sistem yang akan dibangun yaitu Sistem Crowdfunding Basiru Menggunakan PHP dan Freamwork Codeigniter dengan platform website. Namun yang menjadi perbedaannya adalah penelitian tersebut menggunakan Framework Laravel, metode penggumpulan yang digunakan adalah Library Research yang merupakan cara mengumpulkan data dari beberapa buku, jurnal, skripsi, tesis maupun literatur lainnya yang dapat dijadikan acuan pembahasan dan metode pengembangan yang digunakan adalah metode Waterfall. Sedangkan sistem dalam penelitian ini menggunakan Freamwork Codeigniter, metode pengumpulan data yang digunakan adalah kualitatif dan metode pengembanga yang digunakan adalah metode Spiral. ${ }^{[2]}$ Roslina, Handojo, Wibowo (2016) dengan judul "Aplikasi crowdfunding Sebagai Perantara Penggalangan Dana Berbasis Website dan 10 Facebook Application “. Tujuan penelitian ini untuk menghubungkan antara aplikasi Crowdfunding dengan Media Publikasi Facebook dan newsletter yang dapat diakses langsung baik melaui server ataupun Facebook Canvas.

Penelitian ini memiliki kesamaan dengan sistem yang akan dibangun yaitu Sistem Crowdfunding Basiru Menggunakan PHP dan Freamwork Codeigniter dengan platform website. Namun yang menjadi perbedaannya adalah penelitian tersebut menggunakan Website Slim Framework, Sedangkan sistem dalam penelitian ini menggunakan Website Freamwork Codeigniter. ${ }^{[3]}$ Menurut Yaqin, Tijaniyah (2017) berjudul "Sinergitas E-Crowdfunding Dengan ECommerce Dalam Membantu Pendanaan Sosial Berbasis Web Bootstrap", tujuan dari penelitian ini adalah untuk menerapkan yang bersinergitas dengan e-Commerce yang menggunakan fasilitas responsive, yaitu web bootstrap, dalam membantu pendanaan sosial, sehingga kualitas hidup lebih baik dan berkelanjutan.

Dalam penelitian ini juga memiliki kesamaan dengan sistem yang akan dibangun yaitu Sistem Crowdfunding Basiru Menggunakan PHP dan Freamwork Codeigniter dengan platform website. Namun yang menjadi perbedaannya adalah penelitian tersebut menggunakan metode pengembangan sistemnya menggunakan Model-V, Model-V adalah suatu variasi dari model Waterfall, Sedangkan sistem dalam penelitian ini menggunakan model Spiral. ${ }^{[4]}$ Menurut Avisha, dkk. (2019) dalam jurnalnya yang membahas mengenai "Crowdfunding Sebagai Akses Alternatif Permodalan Berbasis Teknologi Digital Pada Kegiatan Pertanian (Studi Kasus di PT Crowde Membangun Bangsa)'. Crowde merupakan salah satu platform yang menggunakan teknologi finansial dengan mengusung konsep crowdfunding sebagai alternatif permodalan yang dapat diakses oleh petani dengan menggunakan media digital. Untuk metode penlitiannya menggunakan metode Penelitian kualitatif deskriptif untuk mengkaji bagaimana crowdfunding sebagai akses alternatif 
permodalan berbasis teknologi pada kegiatan pertanian.

Penelitian ini memiliki kesamaan dengan sistem yang akan dibangun yaitu Sistem Crowdfunding Basiru Menggunakan PHP dan Freamwork Codeigniter dengan platform website. Yang menjadi persamaannya adalah penelitian tersebut menggunakan metode pengumpulan data yang digunakan adalah metode kualitatif.

\section{Pengertian Rekayasa}

${ }^{[5]}$ (Rianto, 2021) Rekayasa Perangkat Lunak (RPL) adalah suatu disiplin ilmu yang mengulas semua aspek produksi perangkat lunak, dimulai dari tahap awal yaitu communication, requirements capturing (analisa kebutuhan pengguna), specification (menentukan spesifikasi dari kebutuhan pengguna), desain, coding, testing hingga maintenance (pemeliharaan sistem) setelah digunakan.

\section{Pengertian Crowfunding}

${ }^{[6]}$ (Short et al., 2017) Crowdfunding adalah sebuah penggalangan dana secara kolektif yang ditujukan untuk suatu proyek tertentu. Crowdfunding diperkenalkan pertama kali pada tahun 1885 untuk proyek pembangunan patung Liberty di Amerika.

\section{Pengertian Basiru}

Kata basiru dalam bahasa Sumbawa memiliki arti kerja sama atau gotong royong. Gotong royong berasal dari bahasa Jawa, gotong berarti angkat, pikul. Sedangkan royong berati sama-sama. Jadi gotong royong berarti bekerja bersama-sama untuk mencapai suatu hasil yang didambakan atau pengertian lain gotong royong adalah bekerja bersama-sama dalam menyelesaikan pekerjaan dan secara bersama-sama menikmati hasil pekerjaan tersebut secara adil.

\section{Pengertian Framework}

${ }^{[7]}$ Menurut Basuki (2014:12) Framework adalah paket berisi fungsi-fungsi yang biasa digunakan dalam pembuatan aplikasi. Beberapa contoh fungsi standar yang biasa ada sebuah Framework misalnya : email, paging, kalender, tanggal, bahasa, upload file, session, validasi form, tabel, manipulasi gambar, text, string, captcha, enkripsi, proteksi terhadap XSS, security dan lain-lain.

\section{Pengertian Codeigniter}

${ }^{[8]}$ (Arrhioui et al., 2017) Codeigniter adalah kerangka kerja pengembangan aplikasi PHP berdasarkan arsitektur yang terstruktur. Codeigniter memiliki tujuan untuk memberikan alat bantu yang dibutuhkan seperti helpers and libraries untuk mengimplementasi tugas yang biasa dilakukan. Dengan demikian, pengembangan proyek menjadi lebih mudah dan cepat. Dan pengembang tidak perlu menulis lagi dari awal.

\section{METODE PENELITIAN}

Adapun kerangka berpikir atau alur dari penelitian Rekayasa Perangkat Lunak Crowfunding Basiru Menggunakan Pemrograman Php Dan Freamwork Codeigniter adalah sebagai berikut :

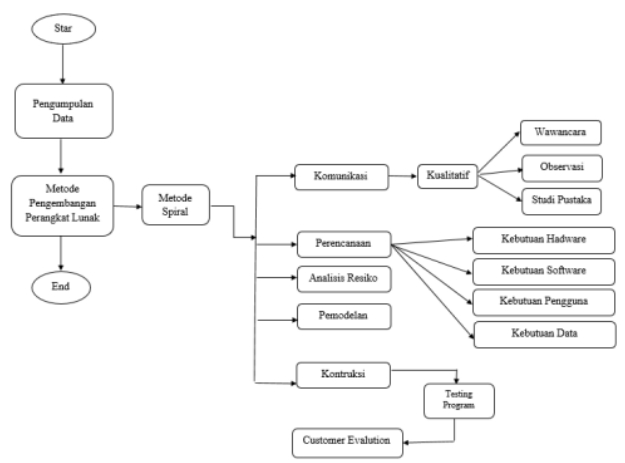

Gambar 1. Alur Metode Penelitian

\section{Metode Pengumpulan Data}

Penjelasan metode kualitatif dan metode pengumpulan data yang digunakan dalam penelitian ini yaitu :

a. Penelitian Kualitatif

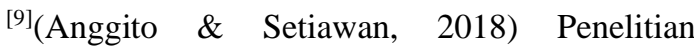
kualitatif merupakan pengumpulan data pada suatu latar ilmiah dengan tujuan menafsirkan fenomena yang terjadi dimana peneliti adalah sebagai instrumen kunci, dan hasil penelitian kualitatif lebih menekankan makna dari pada generalisasi.

b. Wawancara

Dalam wawancara ini penulis melakukan tanya jawab langsung dengan narasumber mengenai tradisi Basiru, dalam hal ini penulis melakukan wawancara di 4 desa yaitu Taliwang, Empang, Batu Alang dan Samapuin. Untuk mendapatkan suatu informasi penulis melakukan wawancara kepada masyarakat setempat mengenai tradisi basiru dengan jumlah 10 orang disetiap desa, yaitu di desa Taliwang, Empang, Samapuin, dan Batu Alang.

c. Observasi

${ }^{[10]}$ Menurut Sugiyono (2017), Observasi sebagai teknik pengumpulan data yang mempunyai ciri spesifik bila dibandingkan dengan teknik yang lainnya. Observasi dilakukan dengan melihat langsung di lapangan.

Berdasarkan pendapat di atas, peneliti menggunakan observasi partisipasi dalam mengumpulkan data mengenai rangkaian prosesi pelaksanaan tradisi basiru.

d. Studi Pustaka 
Dalam studi pustaka ini penulis melakukan pengumpulan data dengan cara meneliti referensi, jurnal yang terkait dengan tradisi basiru.

\section{Metode Pengembangan Perangkat Lunak}

Metode pengembangan perangkat lunak yang digunakan dalam "Sistem Crowfunding Basiru Menggunakan PHP dan Freamwork Codeigniter" adalah spiral. Model spiral dibagi menjadi sejumlah aktifitas kerangka kerja yaitu sebagai berikut :

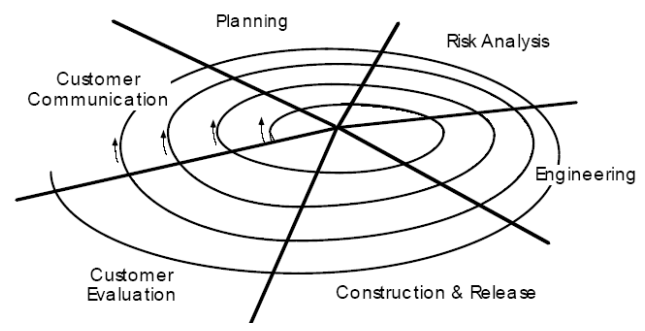

Gambar 2. Metode Spiral

1. Customer communication (Komunikasi)

Pada tahap ini pelanggan dan pengembang melakukan komunikasi terkait sistem crouwfunding basiru berbasis web.

2. Planning (Perencanaan)

Pada tahap ini dibutuhkan untuk menentukan sumberdaya, perkiraan waktu pengerjaan, dan informasi lainnya yang dibutuhkan untuk pengembangan software.

3. Analysis risk (Analisis Resiko)

Aktivitas analisis resiko ini dijalankan untuk menganalisis baik resiko secara teknikal maupun secara manajerial. Tahap inilah yang mungkin tidak ada pada model proses yang juga menggunakan metode iterasi, tetapi hanya dilakukan pada spiral model.

4. Engineering (Pemodelan)

Pada tahap ini dilakukan pemodelan sistem yang akan dibangun sesuai dengan yang telah dikomunikasikan dan direncanakan pada tahap sebelumnya.

5. Construction \& Release (Kontruksi)

Pada tahap ini dilakukan pengetikan kode program menggunakan text editor visual studio code, evaluasi dan pengujian perangkat lunak yang digunakan adalah black box testing.

6. Customer evaluation

Setelah sistem selesai dibuat maka dilakukan penyerahan system kepada pelanggan atau pengguna.

\section{Rancangan Sistem}

Use Case Diagram

a. Use Case Diagram Admin
Berikut ini merupakan use case diagram admin Sistem Crowfunding Basiru Berbasis Web:

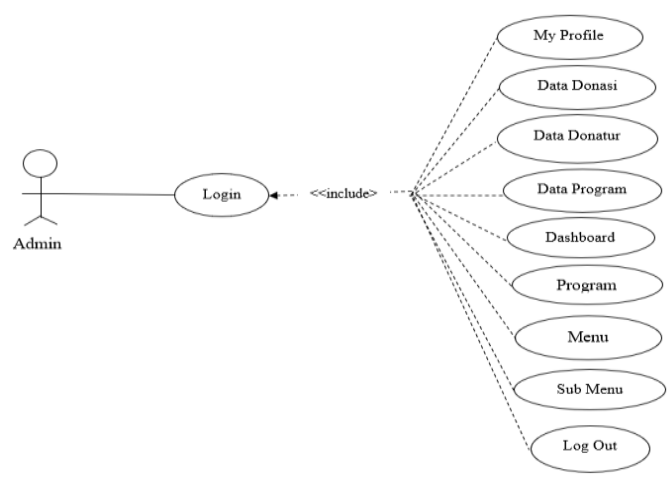

Gambar 3 Use Case Diagram Admin

b. Use Case Diagram Donatur

Berikut ini merupakan use case diagram donatur Sistem Crowfunding Basiru Berbasis Web:

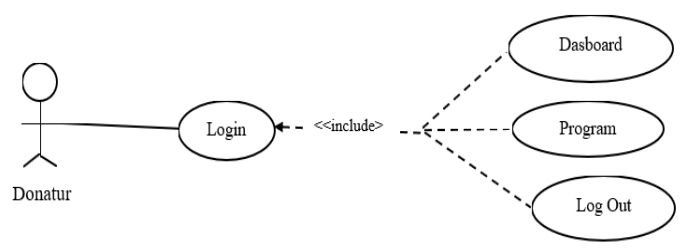

Gambar 4 Use Case Diagram Donatur

\section{Activity Diagram}

Activity diagram menggambarkan alur proses dari setiap fungsi yang terdapat didalam sistem. Berikut alur activity diagram dari Rekayasa Perangkat Lunak Crowfunding Basiru Menggunakan Pemrograman Php Dan Freamwork Codeigniter.

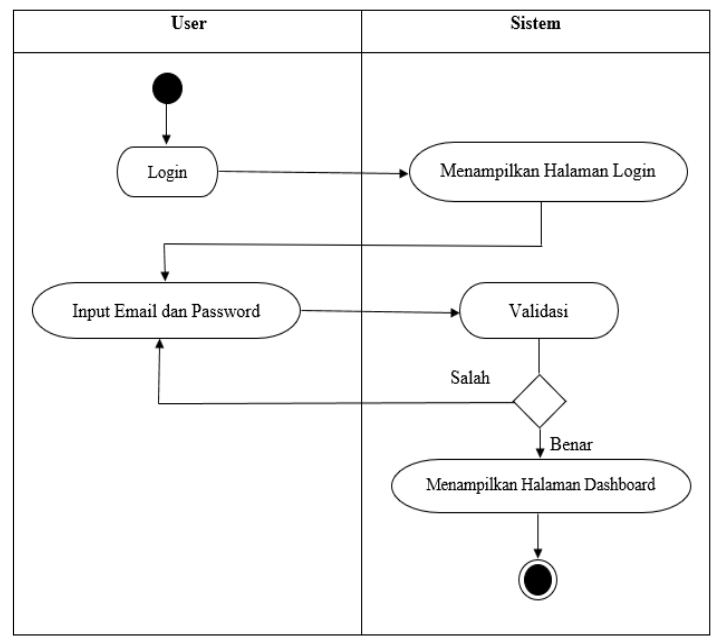

Gambar 5 Activity Diagram

\section{Sequence Diagram}

Rancangan sequence diagram bertujuan untuk menggambarkan bagaimana interaksi antara objek yang terdapat dalam sistem. Pada rancangan sequence diagram Rekayasa Perangkat Lunak Crowfunding Basiru Menggunakan Pemrograman Php Dan Freamwork Codeigniter ini terdapat beberapa menu 
inti yang dimulai dari login, my profile, data donasi, data donatur, data program, dashboard, program, menu management, sub menu management dan logout.

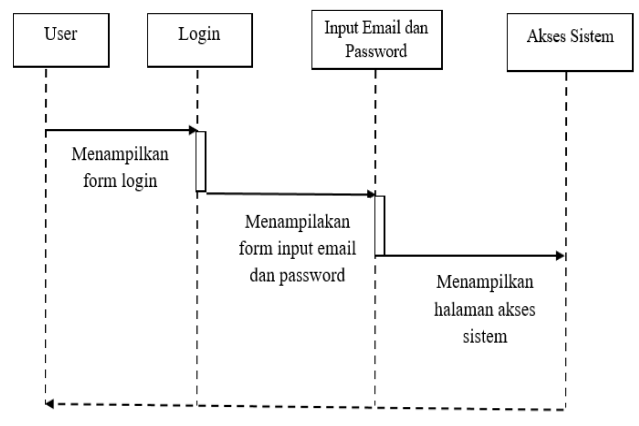

Gambar 6 Sequence Diagram Login

\section{Class Diagram}

Rancangan class diagram menggambarkan interaksi dari class yang ditunjuk dengan garis penghubung antar class. Berikut ini adalah rancangan class diagram dari Rekayasa Perangkat Lunak Crowfunding Basiru Menggunakan Pemrograman Php Dan Freamwork Codeigniter:

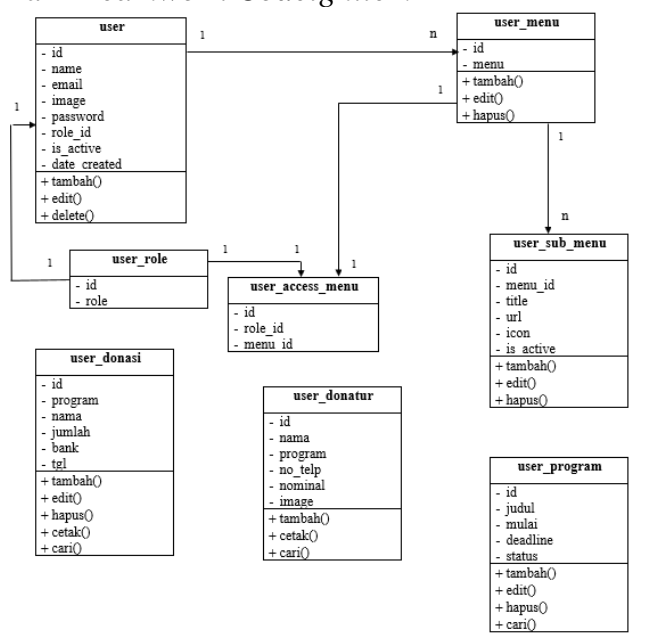

Gambar 7 Class Diagram Sistem Crowfunding Basiru

\section{HASIL DAN PEMBAHASAN}

Implementasi Program

a. Halaman Login

Gambar berikut merupakan tampilan awal ketika pengelola admin akan masuk ke sistem.

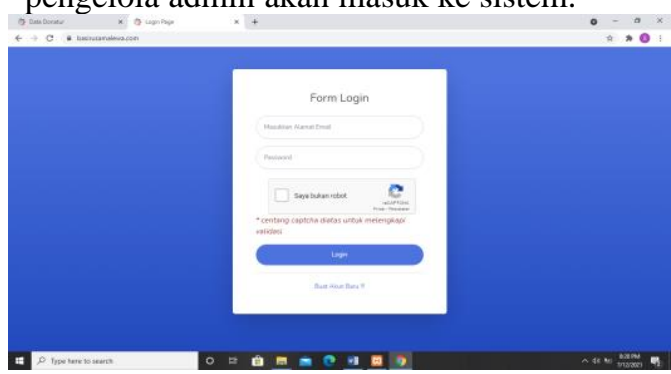

Gambar 8 Halaman Login

b. Halaman Registrasi
Berikut ini implementasi halaman Registrasion Sistem Crowfunding Basiru berbasis web sebagai berikut:

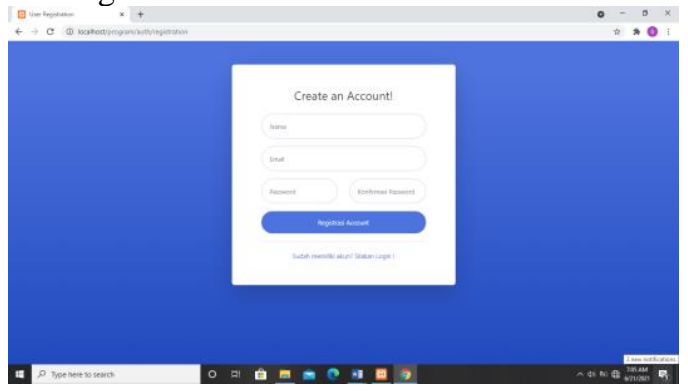

Gambar 9 Halaman registrasi

c. Halaman Dashboard

Gambar berikut merupakan tampilan dashboard ketika admin berhasil login ke sistem.

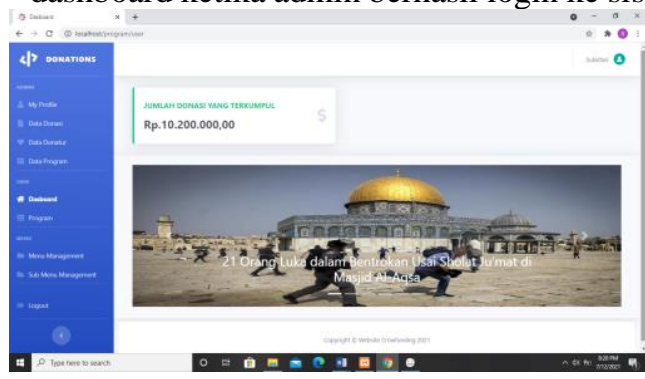

Gambar 10 Halaman Dashboard

Pada halaman dashboard, admin dapat melihat jumlah donasi dari donatur yang sudah terkumpul dari semua program.

d. Halaman Program

Berikut ini implementasi halaman program Sistem Crowfunding Basiru berbasis web sebagai berikut:

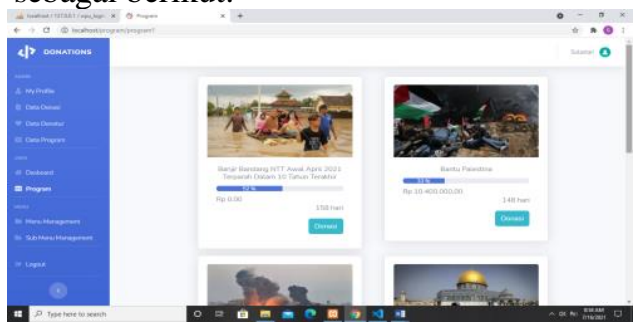

Gambar 11 Halaman Program

\section{KESIMPULAN DAN SARAN}

\section{Kesimpulan}

Dari hasil analisa dan perencanaan perangkat lunak yang telah dilakukan sebelumnya, maka penulis dapat mengambil kesimpulan bahwa Rekayasa Perangkat Lunak Crowfunding Basiru Menggunakan Pemrograman Php Dan Freamwork Codeigniter telah selesai dibangun dengan metode penelitian kualitatif serta menggunakan metode spiral sebagai metode pengembangan perangkat lunak, dan dibangun menggunakan Visual Studio Code dengan bahasa 
pemograman $P H P$ serta $M y S Q L$ sebagai databasenya.

Didalam aplikasi basiru terdapat fitur-fitur yang dapat dimanfaatkan pengguna aplikasi basiru yaitu daftar lebih mudah yang dimana pengguna aplikasi basiru dapat lebih mudah dalam melakukan registrasi ataupun pendaftaran di aplikasi basiru. pengguna dapat menggunakan akses sign up / login menggunakan email yang nantinya didaftar pengguna, tidak ada batasan minimal dan maksimal untuk jumlah donasi dalam aplikasi basiru, dan pilihan pembayaran yang dimana metode pembayaran yang ditawarkan diaplikasi basiru ada 2 pilihan yaitu BNI dan BRI. Dengan dibangunnya Rekayasa Perangkat Lunak Crowfunding Basiru Menggunakan Pemrograman Php Dan Freamwork Codeigniter ini, dapat mempermudah admin dalam mengelola data donator, serta mempermudah donatur dalam berdonasi pada aplikasi basiru berbasis web.

\section{Saran}

Berdasarkan kesimpulan yang telah diuraikan diatas, maka terdapat saran-saran adalah sebagai berikut :

1. Membuat notifikasi atau pesan pemberitahuan ketika ada data donatur yang masuk ke tabel data donatur.

2. Menambahkan menu berita didalam menu user.

3. Penelitian ini dapat dijadikan referensi untuk penelitian selanjutnya.

4. Membuat tampilan user interface menjadi lebih menarik.

5. Menambahkan menu lupa password pada halaman form login.

\section{DAFTAR PUSTAKA}

[1] Anggito, A., \& Setiawan, J. (2018). Metode Penelitian Kualitatif. CV. JEJAK.

[2] Avisha, A., Charina, A., Noor, T. I., \& Mukti, G. W. (2019). Crowdfunding sebagai akses alternatif permodalan berbasis teknologi digital pada kegiatan pertanian (studi kasus di PT crowde membangun bangsa). Mimbar Agribisnis: Jurnal Pemikiran Masyarakat Ilmiah Berwawasan Agribisnis, 5(1), 1-22. https://www.researchgate.net/publication/33052 3282_CROWDFUNDING_SEBAGAI_AKSES _ALTERNATIF_PERMODALAN_BERBASI S_TEKNOLOGI_DIGITAL_PADA_KEGIAT AN_PERTANIAN_STUDI_KASUS_DI_PT_C ROWDE_MEMBANGUN_BANGSA.

[3] Basuki Pribadi A. 2014. Proyek Membangun Website Berbasis PHP dengan Codeigniter. Lokomedia, Yogyakarta.

[4] Karim Arrhioui, S. M. (2017). A Model Driven Approach for Modeling and Generating PHP CodeIgniter based Application. Transactions on Machine Learning and Artificial Intelligence, 259-266. https://journals.scholarpublishing.org/index.php /TMLAI/article/download/3189/2132/

[5] https://ejournal.poltektegal.ac.id/index.php/info rmatika/article/viewFile/765/654.

[6] Rianto, I. (2021). Rekayasa Perangkat Lunak. Penerbit Lakeisha.

[7] Saifullah. "Sistem Penggalangan Dana Menggunakan Metode Crowdfunding Pada Lembaga Amil Zakat Infak Dan Sedekah (Lazis) Wahdah Berbasis Website, ".Skripsi. Makassar : Universitas Islam Negeri Alauddin Makassar, $2017 . \quad$ http://repositori.uinalauddin.ac.id/12582/1/Saifullah.pdf.

[8] Short, J. C. et al. (2017) 'Research on Crowdfunding: Reviewing the (Very Recent) Past and Celebrating the Present', Entrepreneurship: Theory and Practice, 41(2), pp. 149-160. doi: 10.1111/etap.12270.

[9] Sugiyono. (2017). Metode Penelitian Pendidikan Pendekatan Kuantitatif, kualitatif, Dan $R \& D$. Bandung : Alfabeta.

[10] Yaqin, M. A., \& Tijaniyah, T. (2017). Sinergitas E-Crowdfunding Dengan E-Commerce Dalam Membantu Pendanaan Sosial Berbasis Web Bootstrap. In Seminar Nasional Teknologi dan Informatika 2017. Muria Kudus University. https://media.neliti.com/media/publications/171 473-ID-sinergitas-e-crowdfunding-dengan-ecomme.pdf 